\title{
Systematic Review \\ The Effect of Curcumin Differs on Individual Cognitive Domains across Different Patient Populations: A Systematic Review and Meta-Analysis
}

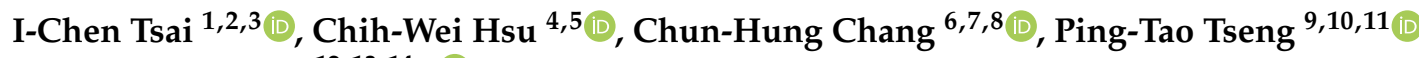 \\ and Ke-Vin Chang 12,13,14,*(D)
}

check for updates

Citation: Tsai, I.-C.; Hsu, C.-W.; Chang, C.-H.; Tseng, P.-T.; Chang, K.-V. The Effect of Curcumin Differs on Individual Cognitive Domains across Different Patient Populations: A Systematic Review and MetaAnalysis. Pharmaceuticals 2021, 14, 1235. https://doi.org/10.3390/ ph14121235

Academic Editors: Víctor López and Filippo Maggi

Received: 8 November 2021

Accepted: 25 November 2021

Published: 28 November 2021

Publisher's Note: MDPI stays neutral with regard to jurisdictional claims in published maps and institutional affiliations.

Copyright: (c) 2021 by the authors. Licensee MDPI, Basel, Switzerland. This article is an open access article distributed under the terms and conditions of the Creative Commons Attribution (CC BY) license (https:/ / creativecommons.org/licenses/by/ $4.0 /)$.
1 Institute of Clinical Medicine, National Yang Ming Chiao Tung University, Taipei 112304, Taiwan; d49624004@ym.edu.tw

2 Congenital Heart Disease Study Group, Asian Society of Cardiovascular Imaging, Seoul 13572, Korea

3 InnovaRad Inc., Taichung 407004, Taiwan

4 Department of Psychiatry, Kaohsiung Chang Gung Memorial Hospital, Chang Gung University College of Medicine, Kaohsiung 83301, Taiwan; harwicacademia@gmail.com

5 Department of Computer Science and Information Engineering, National Cheng Kung University, Tainan 70101, Taiwan

6 Institute of Clinical Medical Science, China Medical University, Taichung 404333, Taiwan; chang763@gmail.com

7 Department of Psychiatry \& Brain Disease Research Center, China Medical University Hospital, Taichung 404332, Taiwan

8 An Nan Hospital, China Medical University, Tainan 709204, Taiwan

9 Prospect Clinic for Otorhinolaryngology \& Neurology, Kaohsiung 811022, Taiwan; ducktseng@gmail.com

10 Institute of Biomedical Sciences, National Sun Yat-sen University, Kaohsiung 804201, Taiwan

11 Department of Psychology, College of Medical and Health Science, Asia University, Taichung 41354, Taiwan

12 Department of Physical Medicine and Rehabilitation, National Taiwan University Hospital, National Taiwan University College of Medicine, Taipei 10048, Taiwan

13 Department of Physical Medicine and Rehabilitation, National Taiwan University Hospital, Bei-Hu Branch, Taipei 10845, Taiwan

14 Center for Regional Anesthesia and Pain Medicine, Wang-Fang Hospital, Taipei Medical University, Taipei 11600, Taiwan

* Correspondence: kvchang011@gmail.com; Tel.: +886-2-2312-3456

Abstract: Curcumin is a polyphenol with strong antioxidant and anti-inflammatory effects that has been shown to be effective in ameliorating cognitive decline in animal studies. However, its clinical effectiveness is inconclusive, and relevant gastrointestinal adverse events (AEs) have been reported. The aim of this meta-analysis was to summarize the existing evidence from randomized controlled trials (RCTs) of effects of curcumin on overall cognitive function, individual cognitive domains, and gastrointestinal AE. The study includes 8 RCTs and 389 participants. A random-effects model was used for the meta-analysis. Compared with the placebo group, the curcumin group was associated with an improvement in working memory (Hedges' $g=0.396,95 \%$ confidence interval $(\mathrm{CI})=0.078$ to $0.714, p=0.015$ ) and a borderline benefit in processing speed (Hedges' $g=0.303$, $95 \% \mathrm{CI}=-0.013$ to $0.619, p=0.06)$. In the domains of language, episodic memory/visual learning, verbal memory, cognitive flexibility/problem solving, and overall cognitive function, no significant difference existed for the comparison between the curcumin and placebo groups. The curcumin group had a significantly higher risk of gastrointestinal AEs than the placebo group (odds ratio $=3.019,95 \%$ $\mathrm{CI}=1.118$ to $8.150, p=0.029)$. In the future, the effects of curcumin on working memory, processing speed, and gastrointestinal AE should be further investigated.

Keywords: cognition; cognitive function; Curcuma longa; curcumin; turmeric 


\section{Introduction}

\subsection{Curcumin in Cognitive Decline Animal Studies}

Curcumin is a polyphenol with strong antioxidant and anti-inflammatory activity [1-3]. It is also the primary active component of the Indian spice turmeric (Curcuma longa) [4] and curry powders [5]. Animal studies have also confirmed that curcumin has protective effects against cognitive decline, both in aging rhesus monkeys [6] and in a streptozotocin-induced dementia rat model [7]. Specifically, curcumin has been found to exhibit various selective effects, including preventing atrophic change and cell loss in the prefrontal cortex compared to the hippocampus $[7,8]$, decreasing neuroinflammation compared to promoting neurogenesis [7], and more positive effects on working memory than on recognition [6].

\subsection{Curcumin in Cognitive Epidemiological Studies and Clinical Trials}

A multi-ethnic Asian study found that, in older adults aged 60 years or more, those who consumed curry "occasionally", "often", or "very often" had significantly better MiniMental State Examination (MMSE) scores than subjects who "never" or "rarely" consumed curry [9]. However, the results of randomized controlled trials (RCTs) are controversial. For example, Ringman et al. found that the curcumin group did not show clinical or biochemical evidence of efficacy in cognitive function tests and biomarkers in patients with Alzheimer's disease [10]. In contrast, Rainey-Smith et al. found that the curcumin group maintained cognitive function during the study period, while the placebo group kept deteriorating [11].

Zhu et al. published a meta-analysis investigating the effect of curcumin on cognition in 2019 [12], summarizing the RCTs available between 2008 and 2018 [10,11,13-16]. They also performed a subgroup analysis according to participants based on the presence of older age, Alzheimer's disease, and schizophrenia. They found that curcumin might be beneficial for the overall cognition of healthy and non-demented older adults. However, in Alzheimer's disease, curcumin seems to have a detrimental effect compared with placebo (standardized mean difference $=-0.9, p=0.002$ ). Since Alzheimer's disease tends to involve the prefrontal cortex [8] and cause corresponding working memory deficits [17], these differences in outcomes across healthy and diseased populations may indicate the selective effects of curcumin on different brain regions and cognitive domains.

\subsection{Individual Cognitive Domains and Gastrointestinal Adverse Events}

The most important age-related changes occur in the domains of working memory, processing speed, and problem-solving (executive function) [18]. Alzheimer's disease is characterized by a decline in working memory, episodic memory, and problem solving [19]. Schizophrenia is known for its multi-domain involvement, including working memory, verbal memory, attention, and executive function [20]. Since earlier human studies usually treat cognitive function as a whole [3,12], the effects of curcumin on different cognitive domains should also be further investigated.

Although curcumin is a safe natural compound that can be ingested up to $6 \mathrm{~g} /$ day for 4-7 weeks [21] without reported toxicity, side effects, such as gastrointestinal upset and diarrhea, have been observed [21-23]. The aim of this study was to review the available RCTs with their corresponding data in a trial registry to provide an updated meta-analysis on the effect of curcumin on overall cognitive function and individual cognitive domains. In this meta-analysis, we also analyzed the side effects and pertinent withdrawal rates of each included trial.

\section{Results}

\subsection{Study Selection}

The PRISMA flow chart of the literature search process is presented in Figure 1. After removing the duplicated articles and excluding non-relevant articles by reading the titles and abstracts, we found 11 RCTs evaluating the effect of curcumin on cognitive function. 
Two articles were excluded due to an intervention duration of less than 8 weeks [14,24]. One article was excluded because it was a review of an already-included RCT [25] (Table S3). Finally, eight articles were included [10,11,13,15,16,26-28]. The clinical trial registry data of these eight articles were also checked and analyzed for qualitative and quantitative analyses [29-35]. In this meta-analysis, all the data needed were successfully retrieved from published articles, accompanying Supplementary Materials, and clinical trial registries.

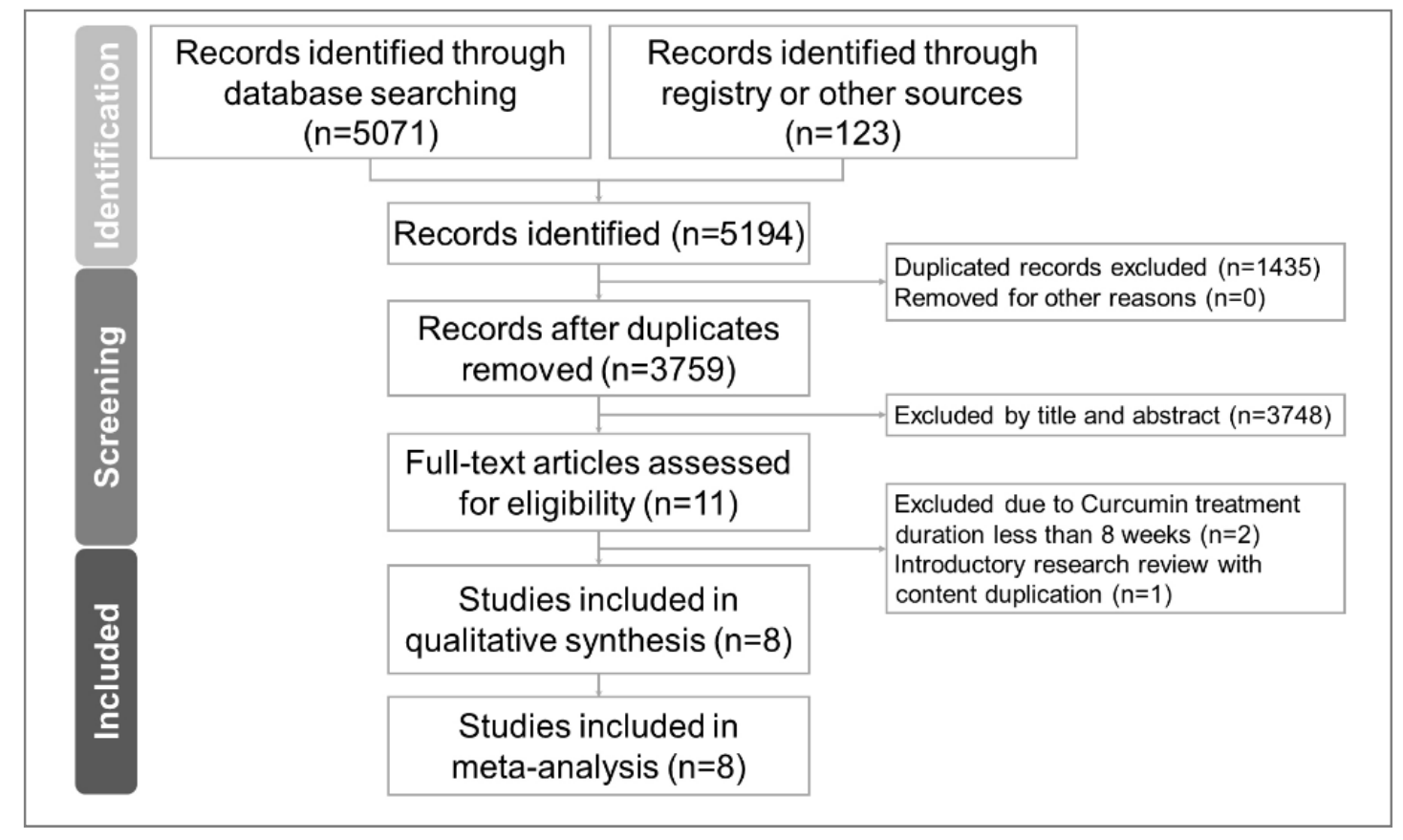

Figure 1. PRISMA 2020 flowchart of current meta-analysis.

In these eight eligible RCTs, there were 389 participants with an age of 65.0 (mean) \pm 10.2 (standard deviation) years and $44.7 \%(\mathrm{n}=174)$ males. All studies were double-blinded. The study duration ranged from 8 to 18 months. The enrolled subjects included older adults in four studies [11,15,27,28], patients with Alzheimer's disease in two studies [10,13], and patients with schizophrenia in two studies $[16,26]$. The curcumin formulations were Theracumin ${ }^{\circledR}$ in three studies $[15,16,26]$, Brain Active ${ }^{\circledR}$ in one study [28], Longvida ${ }^{\circledR}$ in one study [27], Biocurcumax ${ }^{\circledR}$ in one study [11], Curcumin C3 Complex ${ }^{\circledR}$ in one study [10], and powders of Kancor flavors or capsules of Arjuna Natural Extracts in one study [13]. The daily dose of curcumin ranged from 80 to $4000 \mathrm{mg}$.

The curcumin dosage, study arms, and cognitive function test results are summarized in Table 1. For studies with more than one test in a specific cognitive domain, the most representative test was selected by consensus and listed in the first line of the corresponding cells. For example, in Cox et al.'s study published in 2020 [27], there were serial seven subtraction, serial three subtraction, and virtual Morris water maze (vMWM) tests in the working memory domain. Serial seven was selected as the representative test because it had the best differentiating power [17,36]. In another example, in Ringman et al.'s study published in 2012 [10], ADAS-Cog and MMSE were used to assess overall cognitive function. We selected ADAS-Cog because it is more sensitive and detailed than the MMSE (Table 1) [37]. 
Table 1. Summary of the retrieved trials investigating the effect of curcumin on cognitive functions.

\begin{tabular}{|c|c|c|c|c|c|c|c|c|}
\hline Study & Kuszewski et al. & Cox et al. & Kucukgoncu et al. & Wynn et al. & Small et al. & Rainey-Smith et al. & Ringman et al. & Baum et al. \\
\hline $\begin{array}{c}\text { Reference/ } \\
\text { Registry (if available) }\end{array}$ & {$[35,38]$} & {$[27,34]$} & {$[26,33]$} & {$[16,32]$} & {$[15,31]$} & {$[11,30]$} & {$[10,29]$} & [13] \\
\hline Year & 2020 & 2020 & 2019 & 2018 & 2018 & 2016 & 2012 & 2008 \\
\hline Funding/grant & $\begin{array}{l}\text { Blackmores } \\
\text { Institute * }\end{array}$ & Verdure Sciences * & $\begin{array}{l}\text { The State of } \\
\text { Connecticut }\end{array}$ & Not mentioned & $\begin{array}{l}\text { NIH grants } \\
\text { USDE contract } \\
\text { Foundations } \\
\text { Professorships }\end{array}$ & $\begin{array}{c}\text { McCusker } \\
\text { Alzheimer's } \\
\text { Research Foundation } \\
\text { Hollywood Private } \\
\text { Hospital } \\
\text { Research Foundation }\end{array}$ & $\begin{array}{c}\text { J. D. F. } \\
\text { Alzheimer's } \\
\text { Disease } \\
\text { Foundation } \\
\text { Institute for the } \\
\text { Study of Aging }\end{array}$ & $\begin{array}{c}\text { CUHK } \\
\text { Bupa Foundation }\end{array}$ \\
\hline Design & RCT, double-blind & RCT, double-blind & RCT, double-blind & RCT, double-blind & RCT, double-blind & RCT, double-blind & RCT, double-blind & RCT, double-blind \\
\hline Allocation conceal & $\begin{array}{l}\text { Independent } \\
\text { investigator }\end{array}$ & External staff & Not mentioned & Not mentioned & Research pharmacy & Not mentioned & $\begin{array}{l}\text { Research } \\
\text { pharmacy }\end{array}$ & Not mentioned \\
\hline Randomization & $\begin{array}{l}\text { Minimization } \\
\text { method }\end{array}$ & Stratified & Not mentioned & Not mentioned & $\begin{array}{l}\text { Randomization } \\
\text { table }\end{array}$ & Not mentioned & $\begin{array}{c}\text { Block } \\
\text { randomization }\end{array}$ & Stratified \\
\hline Study duration & 16 weeks & 12 weeks & 8 weeks & 8 weeks & 18 months & 12 months & 24 weeks & 6 months \\
\hline Subjects & $\begin{array}{l}\text { Overweight older } \\
\text { adults }\end{array}$ & Healthy older adults & Schizophrenia & Schizophrenia & $\begin{array}{l}\text { Non-demented older } \\
\text { adults }\end{array}$ & Older adults & $\begin{array}{l}\text { Alzheimer's } \\
\text { disease }\end{array}$ & $\begin{array}{l}\text { Alzheimer's } \\
\text { disease }\end{array}$ \\
\hline Curcumin product & $\begin{array}{l}\text { Brain Active }^{\circledR} \\
(\text { Longvida }\end{array}$ & Longvida $^{\circledR}$ & Theracumin $^{\circledR}$ & Theracumin $^{\circledR}$ & Theracumin $^{\circledR}$ & Biocurcumax ${ }^{\circledR}$ & $\begin{array}{c}\text { Curcumin C3 } \\
\text { complex }^{\circledR}\end{array}$ & $\begin{array}{l}\text { Powder or } \\
\text { capsule }\end{array}$ \\
\hline $\begin{array}{l}\text { Curcumin } \\
\text { manufacturer }\end{array}$ & Blackmores & Verdure Sciences & Theravalues & Theravalues & Theravalues & Arjuna Natural & Sabinsa & $\begin{array}{l}\text { Kancor Flavors } \\
\text { Arjuna Natural }\end{array}$ \\
\hline Curcumin arms $(\mathrm{N})$ & $\begin{array}{c}160 \mathrm{mg} / \mathrm{d} \\
\text { curcumin (31) } \\
\text { Placebo (32) }\end{array}$ & $\begin{array}{c}80 \mathrm{mg} / \mathrm{d} \\
\text { curcumin }(42) \\
\text { Placebo (43) } \\
\text { (12 weeks: } 39 / 40)\end{array}$ & $\begin{array}{c}180 \mathrm{mg} / \mathrm{d} \\
\text { curcumin }(6) \\
\text { Placebo (6) } \\
(8 \text { weeks: } 5 / 5)\end{array}$ & $\begin{array}{c}360 \mathrm{mg} / \mathrm{d} \\
\text { curcumin (17) } \\
\text { Placebo (19) }\end{array}$ & $\begin{array}{c}180 \mathrm{mg} / \mathrm{d} \\
\text { curcumin (21) } \\
\text { Placebo (19) }\end{array}$ & $\begin{array}{c}1.32 \mathrm{~g} / \mathrm{d} \\
\text { curcuminoids (39) } \\
\text { Placebo (57) }\end{array}$ & $\begin{array}{c}2 \mathrm{~g} / \mathrm{d} \\
\text { curcuminoids (10) } \\
4 \mathrm{~g} / \mathrm{d} \\
\text { curcuminoids (9) } \\
\text { Placebo (11) }\end{array}$ & $\begin{array}{c}1 \mathrm{~g} / \mathrm{d} \\
\text { curcuminoids (8) } \\
4 \mathrm{~g} / \mathrm{d} \\
\text { curcuminoids (11) } \\
\text { Placebo (8) }\end{array}$ \\
\hline Age (years) & $\begin{array}{c}160 \mathrm{mg} / \mathrm{d}: 65.7 \pm 1.4 \\
\text { Placebo: } 65.8 \pm 1.4\end{array}$ & $\begin{array}{c}80 \mathrm{mg} / \mathrm{d}: 67.8 \pm 6.0 \\
\text { Placebo: } 68.4 \pm 6.7\end{array}$ & $41.3 \pm 12.7$ & $\begin{array}{l}360 \mathrm{mg} / \mathrm{d}: 50.1 \pm 9.6 \\
\text { Placebo: } 50.9 \pm 10.6\end{array}$ & $\begin{array}{c}180 \mathrm{mg} / \mathrm{d}: 63.1 \pm 8.4 \\
\text { Placebo: } 62.9 \pm 9.4\end{array}$ & $66 \pm 6.6$ & $\begin{array}{c}2 \mathrm{~g} / \mathrm{d}: 76.7 \pm 5.6 \\
4 \mathrm{~g} / \mathrm{d}: 75.3 \pm 6.9 \\
\text { Placebo: } 70.2 \pm 12.4\end{array}$ & $\begin{array}{r}1 \mathrm{~g} / \mathrm{d}: 69.0 \pm 10.9 \\
4 \mathrm{~g} / \mathrm{d}: 73.4 \pm 6.6 \\
\text { Placebo: } 77.8 \pm 7.7\end{array}$ \\
\hline Male $\%$ & $\begin{array}{l}160 \mathrm{mg} / \mathrm{d}: 48 \% \\
\text { Placebo: } 44 \%\end{array}$ & $\begin{array}{l}80 \mathrm{mg} / \mathrm{d}: 50 \% \\
\text { Placebo: } 48.84 \%\end{array}$ & Total: $75 \%$ & $\begin{array}{l}360 \mathrm{mg} / \mathrm{d}: 64.7 \% \\
\text { Placebo: } 100 \%\end{array}$ & $\begin{array}{c}180 \mathrm{mg} / \mathrm{d}: 43 \% \\
\text { Placebo: } 47 \%\end{array}$ & $\begin{array}{l}1.32 \mathrm{~g} / \mathrm{d}: 33.3 \% \\
\text { Placebo: } 26.3 \%\end{array}$ & $\begin{array}{c}2 \mathrm{~g} / \mathrm{d}: 33 \% \\
4 \mathrm{~g} / \mathrm{d}: 30 \% \\
\text { Placebo: } 45 \%\end{array}$ & $\begin{array}{c}1 \mathrm{~g} / \mathrm{d}: 12.5 \% \\
4 \mathrm{~g} / \mathrm{d}: 27.3 \% \\
\text { Placebo: } 37.5 \%\end{array}$ \\
\hline Cognition domains & NIH toolbox+ & E-prime 2.0 & MCCB & MCCB & Customized & Customized & ADAS-Cog \& MMSE & MMSE \\
\hline
\end{tabular}


Table 1. Cont.

\begin{tabular}{|c|c|c|c|c|c|c|c|c|}
\hline Study & Kuszewski et al. & Cox et al. & Kucukgoncu et al. & Wynn et al. & Small et al. & Rainey-Smith et al. & Ringman et al. & Baum et al \\
\hline Overall & Overall performance & N/A & Composite score & MCCB T-score & $\mathrm{N} / \mathrm{A}$ & $\begin{array}{c}\text { MoCA } \\
\text { Non-computerized } \\
\text { and } \\
\text { Computerized } \\
\text { composite scores }\end{array}$ & $\begin{array}{l}\text { ADAS-Cog } \\
\text { MMSE }\end{array}$ & MMSE \\
\hline Working memory & Working memory & $\begin{array}{c}\text { Serial } 7 \text { subtraction } \\
\text { Serial } 3 \text { subtraction } \\
\text { vMWM }\end{array}$ & Working memory & N/A & $\mathrm{N} / \mathrm{A}$ & $\mathrm{N} / \mathrm{A}$ & N/A & N/A \\
\hline Processing speed & Processing speed & N/A & Processing speed & N/A & $\begin{array}{l}\text { Trail making test } \\
\text { part A }\end{array}$ & $\begin{array}{l}\text { Wechsler digit } \\
\text { symbol scale }\end{array}$ & N/A & N/A \\
\hline Language & Language & N/A & $\mathrm{N} / \mathrm{A}$ & $\mathrm{N} / \mathrm{A}$ & $\mathrm{N} / \mathrm{A}$ & COWAT & N/A & $\mathrm{N} / \mathrm{A}$ \\
\hline $\begin{array}{l}\text { Episodic memory } \\
\text { /visual learning }\end{array}$ & Episodic memory & N/A & Visual learning & N/A & $\begin{array}{l}\text { BVMT-R recall } \\
\text { BVMT-R delay }\end{array}$ & $\mathrm{N} / \mathrm{A}$ & N/A & $\mathrm{N} / \mathrm{A}$ \\
\hline Verbal memory & Verbal memory & $\begin{array}{c}\text { DATT recognition } \\
\text { accuracy } \\
\text { DATT response time }\end{array}$ & Verbal learning & N/A & $\begin{array}{l}\text { BSRT CLTR } \\
\text { BSRT total } \\
\text { BSRT long-term } \\
\text { storage }\end{array}$ & $\begin{array}{l}\text { RAVLT list A trial } \\
1-5 \text { total } \\
\text { RAVLT short-term } \\
\text { recall } \\
\text { RAVLT delayed } \\
\text { recall }\end{array}$ & N/A & N/A \\
\hline $\begin{array}{c}\text { Cognitive } \\
\text { flexibility/problem } \\
\text { solving }\end{array}$ & Cognitive flexibility & Arrow flankers test & $\begin{array}{l}\text { Attention-vigilance } \\
\text { Problem solving }\end{array}$ & $\mathrm{N} / \mathrm{A}$ & $\mathrm{N} / \mathrm{A}$ & $\mathrm{N} / \mathrm{A}$ & $\mathrm{N} / \mathrm{A}$ & $\mathrm{N} / \mathrm{A}$ \\
\hline Social cognition & N/A & N/A & Social cognition & N/A & N/A & N/A & N/A & N/A \\
\hline Fluid cognition & Fluid cognition & $\mathrm{N} / \mathrm{A}$ & $\mathrm{N} / \mathrm{A}$ & $\mathrm{N} / \mathrm{A}$ & $\mathrm{N} / \mathrm{A}$ & $\mathrm{N} / \mathrm{A}$ & $\mathrm{N} / \mathrm{A}$ & $\mathrm{N} / \mathrm{A}$ \\
\hline
\end{tabular}

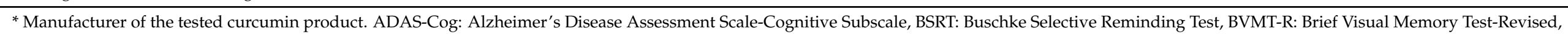

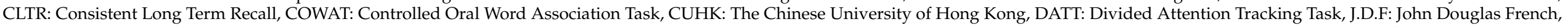

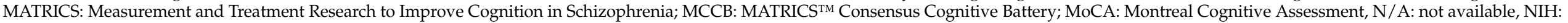
National Institute of Health, RCT: Randomized Controlled Trial, USDE: United States Department of Energy, vMWM: Virtual Morris Water Maze. 


\subsection{Methodological Quality of Included Studies}

Regarding the overall methodological quality of the studies included in the metaanalysis, $75 \%$ of the studies had low risk of bias, $12.5 \%$ had some risk of bias, and $12.5 \%$ had a high risk of bias (Figure 2). In a detailed assessment, one study was rated as "high" risk of bias in missing outcome data [11] and two studies were rated as "some" risk of bias in selective reporting [11,15]. Notably, we rated Wynn et al.'s study [16] as "low" risk of bias in all aspects, which was different from the assessment from Zhu et al.'s meta-analysis [39] in the domain of incomplete outcome data and selective reporting [12]. This was because Wynn et al. disclosed the full results on ClinicalTrials.gov after Zhu et al.'s article was published [32]. The reasons for rating "some" and "high" risk of bias are listed in Table 2.

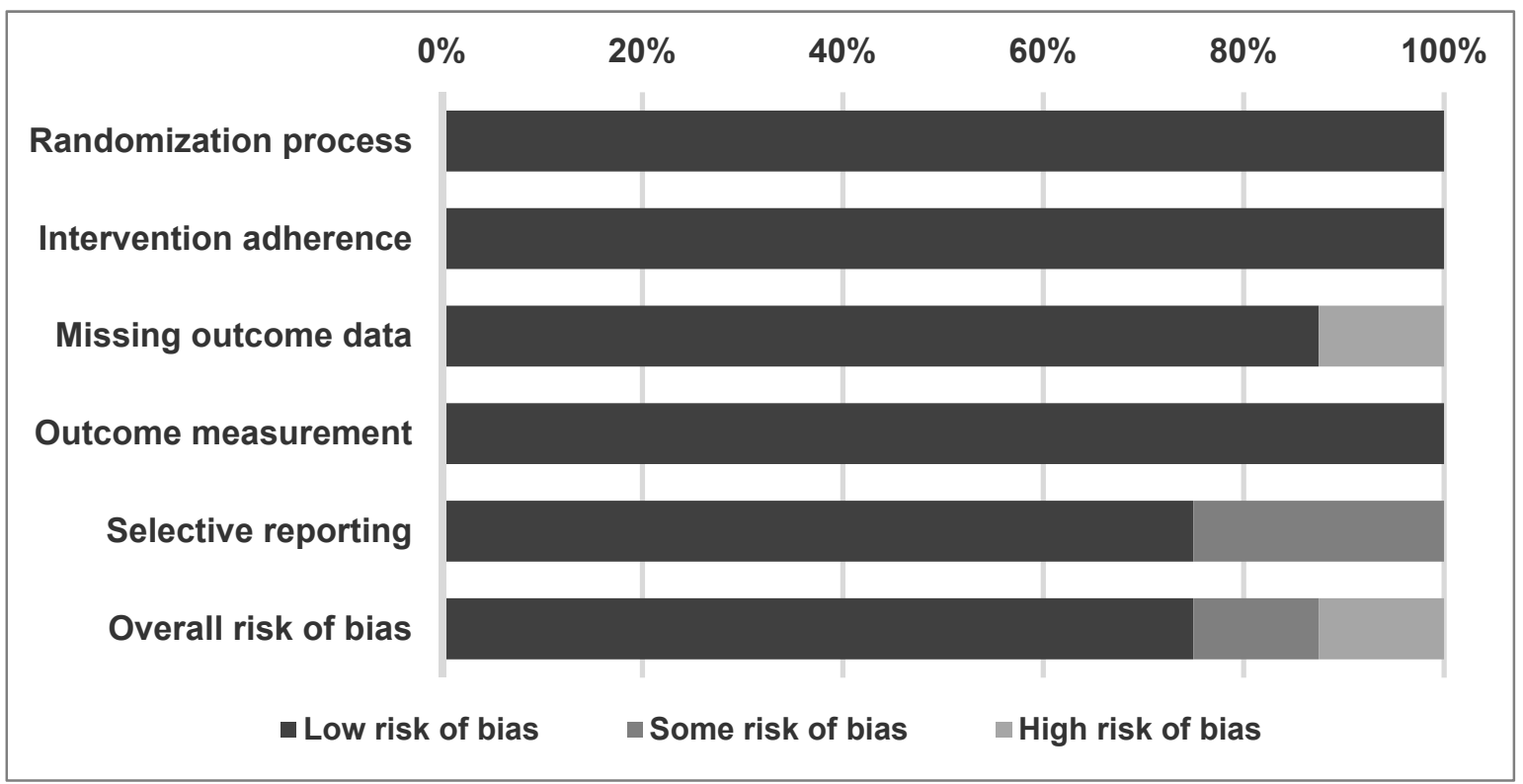

Figure 2. Summary of quality assessment of studies included in the meta-analysis using Cochrane risk of bias 2 tool.

Table 2. Detailed quality assessment of included studies using Cochrane risk of bias 2 tool.

\begin{tabular}{|c|c|c|c|c|c|c|c|c|}
\hline & $\begin{array}{l}\text { Kuszewski } \\
\text { et al. }\end{array}$ & $\begin{array}{l}\text { Cox } \\
\text { et al. }\end{array}$ & $\begin{array}{l}\text { Kucukgoncu } \\
\text { et al. }\end{array}$ & $\begin{array}{l}\text { Wynn } \\
\text { et al. }\end{array}$ & $\begin{array}{l}\text { Small } \\
\text { et al. }\end{array}$ & $\begin{array}{l}\text { Rainey-Smith } \\
\text { et al. }\end{array}$ & $\begin{array}{l}\text { Ringman } \\
\text { et al. }\end{array}$ & $\begin{array}{l}\text { Baum } \\
\text { et al. }\end{array}$ \\
\hline $\begin{array}{c}\text { Reference/ } \\
\text { Registry } \\
\text { (if available) }\end{array}$ & {$[35,38]$} & {$[27,34]$} & {$[26,33]$} & {$[16,32]$} & {$[15,31]$} & {$[11,30]$} & {$[10,29]$} & [13] \\
\hline Year & 2020 & 2020 & 2019 & 2018 & 2018 & 2016 & 2012 & 2008 \\
\hline $\begin{array}{l}\text { Randomization } \\
\text { process }\end{array}$ & $\mathrm{L}$ & $\mathrm{L}$ & $\mathrm{L}$ & $\mathrm{L}$ & $\mathrm{L}$ & $\mathrm{L}$ & $\mathrm{L}$ & $\mathrm{L}$ \\
\hline $\begin{array}{l}\text { Intervention } \\
\text { adherence }\end{array}$ & $\mathrm{L}$ & $\mathrm{L}$ & $\mathrm{L}$ & $\mathrm{L}$ & $\mathrm{L}$ & $\mathrm{L}$ & $\mathrm{L}$ & $\mathrm{L}$ \\
\hline $\begin{array}{c}\text { Missing } \\
\text { outcome data }\end{array}$ & $\mathrm{L}$ & $\mathrm{L}$ & $\mathrm{L}$ & $\mathrm{L}$ & $\mathrm{L}$ & $\mathrm{H}^{3}$ & $\mathrm{~L}$ & $\mathrm{~L}$ \\
\hline $\begin{array}{c}\text { Outcome } \\
\text { measurement }\end{array}$ & $\mathrm{L}$ & $\mathrm{L}$ & $\mathrm{L}$ & $\mathrm{L}$ & $\mathrm{L}$ & $\mathrm{L}$ & $\mathrm{L}$ & $\mathrm{L}$ \\
\hline $\begin{array}{l}\text { Selective } \\
\text { reporting }\end{array}$ & $\mathrm{L}$ & $\mathrm{L}$ & $\mathrm{L}$ & $\mathrm{L}^{1}$ & $S^{2}$ & $\mathrm{~S}^{4}$ & $\mathrm{~L}$ & $\mathrm{~L}$ \\
\hline $\begin{array}{c}\text { Overall } \\
\text { RoB }\end{array}$ & $\mathrm{L}$ & $\mathrm{L}$ & $\mathrm{L}$ & $\mathrm{L}^{1}$ & $S$ & $\mathrm{H}$ & $\mathrm{L}$ & $\mathrm{L}$ \\
\hline
\end{tabular}

$\mathrm{H}$, high risk of bias; L, low risk of bias; RoB, risk of bias; $\mathrm{S}$, risk of bias. ${ }^{1}$ The assessment result is different from a previous meta-analysis 
conducted by Zhu et al. [12], because the authors then published results on ClinicalTrials.gov (accessed on 13 August 2021 ) and provided full results online. ${ }^{2}$ The outcome was assumed to be reported at baseline and at the 18-month follow-up based on information from the trial registration website [31]. However, 6- and 12-month results were provided in the published article in addition to baseline and 18-month results [15]. Since we did not use the 6- and 12-month data for meta-analysis, some risk of bias was considered. ${ }^{3}$ This study was determined to have a high risk of bias in missing outcomes because many adverse event-related withdrawals were noted, especially in the curcumin group (21/80) compared with the placebo group (2/80). ${ }^{4}$ The trial was registered for baseline and 12-month evaluations [30]. However, 6-month results were provided in the published article in addition to the baseline and 12-month results [11]. Since we did not use the 6-month data for meta-analysis, some risk of bias was considered.

\subsection{Primary Outcome}

\subsubsection{Overall Cognitive Function}

Six out of the eight enrolled studies had data on overall cognitive assessment. No statistical difference (Hedges' $g=0.340,95 \% \mathrm{CI}=-0.353$ to $1.033, p=0.337, I^{2}=0.0 \%$ ) was observed between the curcumin and placebo groups (Figure 3 ).

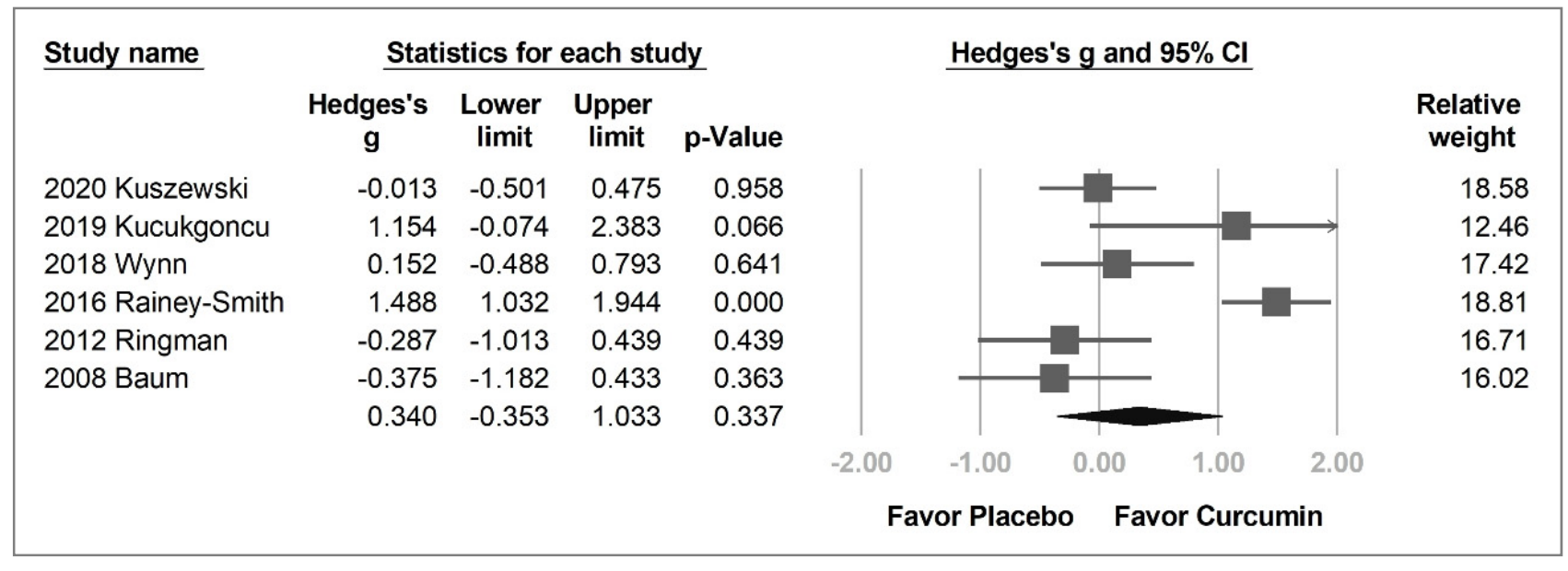

Figure 3. Forest plot of the effect of curcumin on the overall cognitive function.

The participants were further grouped into older adults, patients with Alzheimer's disease, and patients with schizophrenia for subgroup analysis. However, regardless of the group, curcumin was no more effective than placebo in overall cognitive function (older adults: Hedges' $g=0.740,95 \% \mathrm{CI}=-0.731$ to $2.211, p=0.324, I^{2}=94.9 \%$; Alzheimer's disease: Hedges' $g=-0.326,95 \% \mathrm{CI}=-0.866$ to $0.214, p=0.237, I^{2}=0.0 \%$; schizophrenia: Hedges' $g=0.511,95 \% \mathrm{CI}=-0.431$ to $1.452, p=0.288, I^{2}=50.2 \%$ ) (Figure $\mathrm{S} 1$ ).

In the six studies analyzed, Rainey-Smith et al.'s [11] and Kucukgoncu's [26] studies were the only two with ES more than 1.0, and were considered to be the source of heterogeneity.

\subsubsection{Individual Cognitive Domains}

With regards to the individual domains, working memory was the only domain with significant between-group differences. From the data of the three enrolled studies [26-28], the curcumin group significantly improved working memory compared with the placebo group (Hedges' $g=0.396,95 \% \mathrm{CI}=0.078$ to $0.714, p=0.015$ ) without significant heterogeneity $\left(I^{2}=0.0 \%\right)$ (Figure 4$)$. 


\begin{tabular}{|c|c|c|c|c|c|c|c|c|c|c|}
\hline \multirow[t]{2}{*}{ Study name } & \multicolumn{4}{|c|}{ Statistics for each study } & & \multicolumn{5}{|c|}{ Hedges's g and $95 \% \mathrm{Cl}$} \\
\hline & $\begin{array}{c}\text { Hedges's } \\
\text { g }\end{array}$ & $\begin{array}{l}\text { Lower } \\
\text { limit }\end{array}$ & $\begin{array}{l}\text { Upper } \\
\text { limit }\end{array}$ & p-Value & & & & & & $\begin{array}{c}\text { Relative } \\
\text { weight }\end{array}$ \\
\hline 2020 Kuszewski & 0.270 & -0.220 & 0.760 & 0.281 & & & & & & 42.07 \\
\hline 2020 Cox & 0.400 & -0.044 & 0.844 & 0.077 & & & & & & 51.24 \\
\hline \multirow[t]{4}{*}{2019 Kucukgoncu } & 1.155 & -0.074 & 2.384 & 0.065 & & & & 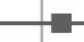 & & 6.69 \\
\hline & 0.396 & 0.078 & 0.714 & 0.015 & & & & & & \\
\hline & & & & & -2.00 & -1.00 & 0.00 & 1.00 & 2.00 & \\
\hline & & & & \multicolumn{7}{|c|}{ Favor Placebo Favor Curcumin } \\
\hline
\end{tabular}

Figure 4. Forest plot of the effect of curcumin on working memory.

Sensitivity analysis was also performed. In working memory, we selected a serial seven subtraction test to represent Cox et al.'s study [27], rather than serial three subtraction or vMWM tests. To confirm that the result was not affected by the decision, we used serial three subtraction and vMWM tests instead. The substitutions did not alter the statistical significance (serial three subtraction: Hedges' $g=0.333,95 \% \mathrm{CI}=0.016$ to $0.650, p=0.039$, $I^{2}=0.0 \%$; vMWM: Hedges' $g=0.454,95 \% \mathrm{CI}=0.135$ to $0.773, p=0.005, I^{2}=0.0 \%$ ) (Figures S2 and S3).

The processing speed in the curcumin group was also likely to be better than that in the placebo group with a borderline $p$ value (Hedges' $g=0.303,95 \% \mathrm{CI}=-0.013$ to 0.619 , $p=0.060, I^{2}=19.5 \%$ ) (Figure 5).

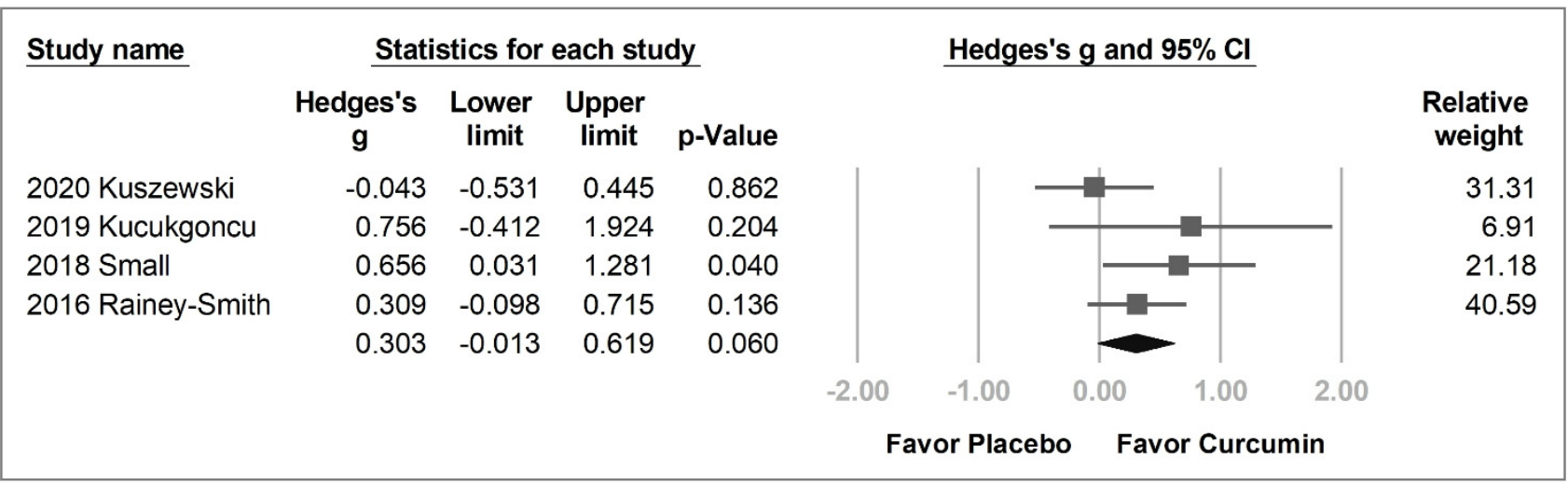

Figure 5. Forest plot of effect of curcumin on processing speed.

There was no statistical difference between the curcumin and placebo groups in the domains of language (Hedges' $g=-0.633,95 \% \mathrm{CI}=-1.878$ to $0.612, p=0.319, I^{2}=93.0 \%$; Figure S4), episodic memory/visual learning (Hedges' $g=-0.075,95 \% \mathrm{CI}=-0.438$ to $0.287, p=0.683, I^{2}=0.0 \%$; Figure S5), verbal memory (Hedges' $g=0.273,95 \% \mathrm{CI}=-0.190$ to $0.739, p=0.248, I^{2}=22.3 \%$; Figure S6), and cognitive flexibility/problem solving (Hedges' $g=0.050,95 \% \mathrm{CI}=-0.482$ to $0.583, p=0.853, I^{2}=44.4 \%$; Figure S7).

\subsection{Secondary Outcomes}

The curcumin group was likely to have a higher overall withdrawal rate than the placebo group, with a borderline $p$-value $(\mathrm{OR}=1.643,95 \% \mathrm{CI}=0.980-2.753, p=0.059$, $I^{2}=5.5 \%$; Figure S8). The adverse event-related withdrawal rate and adverse event rates were not significantly higher in the curcumin group, with an OR of 2.44 (95\% CI = 0.791-6.361, $\left.p=0.128, I^{2}=45.1 \%\right)$ and $2.245\left(95 \% \mathrm{CI}=0.803\right.$ to $\left.6.276, p=0.123, I^{2}=46.5 \%\right)$, respectively (Figures S9 and S10). However, curcumin was associated with significantly more 
gastrointestinal adverse events than the placebo ( $\mathrm{OR}=3.019,95 \% \mathrm{CI}, 1.118-8.150, p=0.029$;

$I^{2}=13.3 \%$; Figure 6).

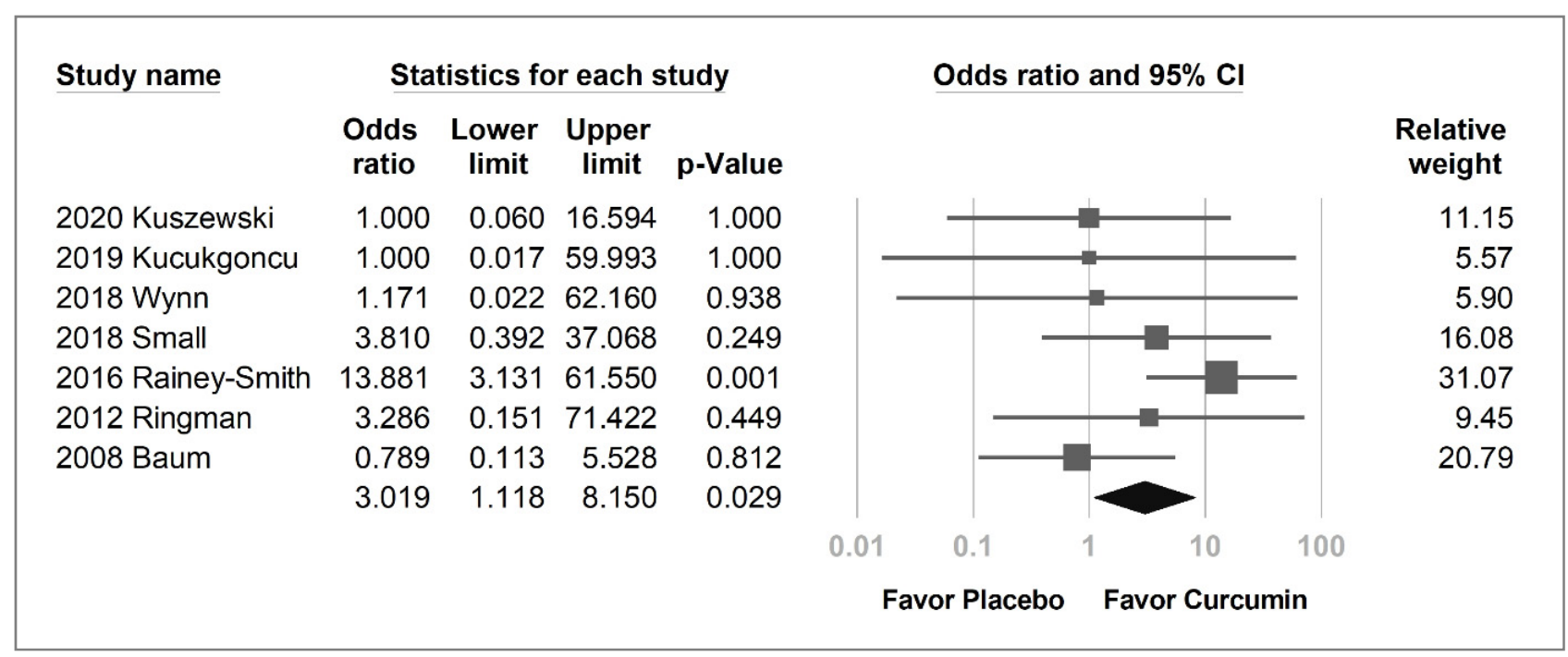

Figure 6. Forest plot of the gastrointestinal adverse event rate of curcumin compared with the placebo group.

\subsection{Publication Bias}

No publication bias was detected in any funnel plot under visual inspection (Figures S11-S20).

\section{Discussion}

\subsection{Main Results}

Our meta-analysis found that curcumin supplementation and placebo regimens did not enhance overall cognitive function. However, curcumin improved working memory performance more than the placebo. This finding was validated by selecting different working memory tests for sensitivity analysis. Curcumin was also likely to be beneficial for processing speed. Finally, a higher rate of gastrointestinal adverse events was observed in the curcumin group than in the placebo group.

\subsection{Possible Mechanisms of the Improved Cognitive Function by Curcumin}

There are multiple pathways related to the cognitive function improvement after the use of curcumin. Anti-inflammation is one of them, since there were studies showing that cognitive declines in schizophrenia and mood disorders were associated with inflammation $[40,41]$. Curcumin can reduce inflammation and provide neuroprotection by inhibiting $\mathrm{NF} K \mathrm{~B}$ and subsequent TNF- $\alpha$ to reduce reactive oxygen species activation [42]. Furthermore, activation of the pathways of phosphatidylinositol-3/protein kinase B/glycogen synthase kinase-3 and phosphatidylinositol-3/protein kinase B/cAMP response elementbinding protein/brain-derived neurotrophic factor were also found to reduce neurodegeneration [43].

\subsection{Evidence Summary of Multisystem Health Benefits of Curcumin}

Regarding the cardiovascular system, Ashtary-Larky et al. summarized nine RCTs and concluded that curcumin may reduce cardiovascular disease risk by improving glycemic and lipid profiles, scaling down inflammation, and reducing systolic blood pressure [44]. With reference to inflammatory diseases, such as ulcerative colitis, a metaanalysis of seven RCTs by Chandan et al. found that curcumin combined with mesalamine was associated with threefold better odds of a clinical response than mesalamine with placebo [45]. For physically active people and athletes, curcumin improved performance by reducing exercise-induced muscle damage and modulating the inflammation caused by physical activity, according to the systematic reviews of Suhett et al.'s and Fernández- 
Lázaro et al. [46,47]. To enhance the effects of cancer therapy, Mansouri et al. systematically reviewed 22 studies, concluding that curcumin could reduce the side effects of chemotherapy or radiotherapy and improve patients' quality of life [48].

Zhu et al. synthesized six RCTs and found that curcumin and placebo did not differ with respect to overall cognitive function. However, Zhu et al. did not investigate the effects of curcumin on different cognitive domains due to the limited number of available studies at that time. Our meta-analysis further divided the cognitive tests into different domains and found that curcumin could improve working memory and possibly processing speed.

These multi-system health benefits are related to antioxidant and anti-inflammatory activities and may also be synergistic [49]. For example, the positive cognitive effects might be related not only to the direct effects of curcumin on neural cells [50], but also to its action on the cardiovascular system, such as protecting the endothelium, maintaining microvascular function, stabilizing cerebrovascular perfusion, and keeping the brain-blood barrier intact [51,52], which can also ameliorate neurodegenerative changes [53].

\subsection{Effects of Curcumin on Different Cognitive Domains}

The reason why working memory and processing speed improved more than other domains after the administration of the curcumin supplement may be related to its selective effect on different regions and cells.

Working memory is a unique, short-term active storage mechanism used to accomplish various cognitive activities [17]. Delayed-response tasks are usually used in animal studies to explore the relationship between working memory function and the underlying neural mechanism [17]. The studies of Watanabe et al. for monkey's neural activity found that different working memory tasks activated overlapping prefrontal neural populations, and the magnitude of activity was related to the difficulty of the task [54,55]. The aforementioned findings indicate that working memory is mostly processed in the prefrontal cortex.

The protective effect of curcumin in the prefrontal cortex has also been demonstrated in animal models. Noorafshan et al. used three different neural damage rat models, including stress-induced, sulfite-induced, and sleep deprivation, and found that curcumin could prevent structural deterioration in neurons and glial cells, and could also counteract behavioral changes $[8,56,57]$. This showed that curcumin had a direct protective effect on the prefrontal cortex and may explain why curcumin was able to effectively improve working memory, as observed in our meta-analysis.

With regards to processing speed, the quantitative neuroimaging study of Magistro et al. on healthy young people found that the speed of processing was correlated with the volume of the white matter in the whole brain [58]. During the process of aging, a decreased overall processing speed and an increased variability of intra-individual processing speed has been observed in the elderly [59]. This decline in processing speed has been found to be accompanied by white matter changes on histopathology and neuroimaging $[60,61]$. The current cortical disconnection theory hypothesizes that a decline in white matter integrity disrupts the information flow within neural networks, which may be the cause of the reduction in processing speed $[62,63]$.

Daverey et al. found that curcumin can inhibit hypoxia, inflammation, and apoptosis associated with white matter injury in rat cells [64]. Naeimi et al. used a rat model of demyelination and found that curcumin could significantly improve myelin repair and maintain white matter integrity [50]. These mechanisms may explain the beneficial effects of curcumin on the processing speed.

In contrast, using a literature search from the electronic database, we did not identify any animal or human studies demonstrating that curcumin could act on Broca's area for language, occipital lobe for visual learning, fronto-temporo-parietal region for verbal memory, and the interaction between the thalamus and prefrontal cortex for cognitive flexibility. This may explain the non-significant results of curcumin for these cognitive domains. 


\subsection{Adverse Gastrointestinal Effects of Curcumin}

Curcumin is categorized as "generally considered as safe" by United States Food and Drug Agency [65]. However, high-dose curcumin directly stimulates the gastrointestinal mucosa. In an extensive report published by the National Toxicology Program (United States), a two-year feeding study found increased incidences of ulcers, hyperplasia, and inflammation of the forestomach, cecum, and colon in male rats and of the cecum in female rats administered curcumin supplement [66]. A phase I clinical trial of oral curcumin included 15 patients, of whom one participant showed nausea and two participants experienced diarrhea, both of whose conditions could be medically controlled or spontaneously resolved [23].

The side effects of gastrointestinal irritation caused by curcumin may be dose-dependent. As experimental studies showed at the cellular level, low-concentration curcumin demonstrated antioxidant effects; however, at higher concentrations, it increased the intracellular reactive oxygen species [67-69]. When the concentration of curcumin in the cerebrospinal fluid reaches the threshold of cognitive benefit, the focal high concentration of curcumin in gastrointestinal mucosa cause inflammation and ulcers, with symptoms including nausea and diarrhea, similar to the observations in rat and mouse studies [66] and a phase I clinical trial [23].

In our study, we also found higher odds of gastrointestinal AEs in the curcumin group. We speculate that in the future, the trials of curcumin, including nutraceuticals designed for higher curcumin bioavailability [42], should emphasize adverse event reporting, and may consider an intention-to-treat study design to better preserve the prognostic balance of randomization [70].

\subsection{Different Formulations and Ingredients}

In the included trials, six different formulations of curcumin were used [71-76]. The core ingredients were produced by five different corporations [72-76]. The different formulations were all developed to enhance the bioavailability of curcumin. For example, Biocurcumax is made of curcumin with turmeric essential oil [73]. Theracumin is made of the submicron curcumin particles with surface preparation for preventing recrystallization [76]. Longvida uses solid lipid curcumin particles to bypass initial hydrolysis and to deliver unglucuronidated (free) curcumin to brain and other target tissues [75]. However, there was no systematic comparison of these different formulations regarding their clinical effectiveness on cognitive function.

In the included eight trials, five used curcumin and three used curcuminoids, which included curcumin, demethoxycurcumin, and bisdemethoxycurcumin. Though these three compounds showed different mechanisms of morphine's rewarding effect in rat brain study [77], curcumin is considered to be the most potent [78,79] and is also the major ingredient (about 75-78\%) in curcuminoids. The results implied that in our meta-analysis, the cognitive improvement and gastro-intestinal adverse events are likely to stem from the effect of curcumin.

\subsection{Limitations}

There are several limitations in our study. First, this meta-analysis synthesized different populations of participants, including older adults, and Alzheimer's disease and schizophrenia patients. The differences in the underlying conditions might be associated with different cognitive changes under curcumin intervention. We performed a subgroup analysis to specifically address this issue, and found no significant difference among the three participant groups (Figure S1). Since the inflammation plays an important role in normal aging brain [80], Alzheimer's disease [81], and schizophrenia [41], the antiinflammatory effects of curcumin seemed similar in the three aforementioned groups. Furthermore, a transdiagnostic meta-analysis is a common and acceptable practice if the potential heterogeneity is well-examined. For example, Zhu et al. included older adults, Alzheimer's disease and schizophrenia patients to evaluate the effect of curcumin in cogni- 
tive function [12], and Dauwan et al. included six different brain disorders to examine the effects of physical exercise on quality of life, depressive symptoms, and cognition [82].

Second, the number of eligible RCTs was small, resulting in only two to six datasets being extracted in each cognitive domain. Nevertheless, the significant benefit of curcumin in the working memory domain remained following the sensitivity analysis, indicating that the result was robust and not likely to be caused by the subjective decision of the index test.

Lastly, the RCTs in this field mostly employed the per-protocol design, which may inherently overestimate the treatment effect and underestimate the adverse-event-related dropout [83]. In this meta-analysis, we also used a per-protocol analysis to prevent distortion of the extracted data. In the future, for those who are designing a new RCT in this field, an intention-to-treat design is suggested to truly reflect the clinical effectiveness of curcumin.

\section{Materials and Methods}

\subsection{General Guidelines}

We followed the instructions of the latest version of PRISMA 2020 guidelines (Table S1) [84] and AMSTAR 2 (Assessing the Methodological Quality of Systematic Reviews) guidelines [85]. This study was registered in https://inplasy.com/inplasy-2021-9-0085/ (accessed on 24 September 2021, registered number: INPLASY202190085) [86].

\subsection{Database Searches and Identification of Eligible Papers}

Two authors (I.-C.T. and K.-V.C.) made independent electronic searches in the PubMed, Embase, ClinicalKey, Cochrane CENTRAL, ProQuest, ScienceDirect, and Web of Science with keyword of ("curcumin" OR "turmeric" OR "ginger" OR "curcuma longa" OR "curcuminoid") AND ("cognitive" OR "cognition" OR "memory" OR “learning" OR "dementia" OR "Alzheimer") through the earliest record up to 18 August 2021. In addition, to include gray literature and unpublished data, we also performed an electronic search on the ClinicalTrials.gov platform. A detailed search strategy is provided in the Supplementary Material (Table S2).

In the initial stage, these two authors screened the titles and abstracts for eligibility through consensus. To expand the pool of potential studies, we scrutinized the reference lists of review articles $[3,12,38,87]$ and performed further manual searches. Later, a third reviewer (P.-T.T.) was consulted in situations in which the two authors could not achieve consensus. No language restrictions were imposed.

\subsection{Inclusion and Exclusion Criteria}

The PICO (population, intervention, comparison, and outcome) setting of the current meta-analysis included: (1) P: human adult participants ( $\geq 20$ years old); (2) I: curcumin oral supplement; (3) C: placebo; and (4) O: changes in the scores of the selected cognitive function tests.

To generate a recruited study list, the following inclusion criteria were used: (1) RCTs with adult human participants ( $\geq 20$ years old), (2) RCTs investigating the difference in results of cognitive function tests after curcumin supplementation or placebo regimens, (3) RCTs with an intervention duration greater than or equal to 8 weeks, and (4) placebocontrolled trials. To be specific, we chose the least treatment duration of 8 weeks, which is the recommended length of curcumin supplement to take effect [88,89].

The exclusion criteria were as follows: (1) studies that were not RCTs; (2) studies that included participants $<20$ years old; (3) studies that did not investigate the influence of curcumin supplement and placebo regimens on cognition; (4) an introductory research review that simply reports previous studies; (5) studies with an intervention duration of less than 8 weeks; (6) studies that lacked placebo or controlled arms. 


\subsection{Methodological Quality Appraisal}

To investigate the methodological quality of the recruited studies, we used version 2 of the Cochrane risk-of-bias tool for randomized trials (RoB 2), which consists of six main items: randomization process, intervention adherence, missing outcome data, outcome measurement, selective reporting, and overall risk of bias [83].

In RoB 2's intervention adherence section, one of the two options should be selected for literature assessment: intention-to-treat (intervention assignment) or per-protocol (intervention adherence). In this meta-analysis, we chose a per-protocol evaluation [83]. Any discrepancy in the opinions of assessments between the two evaluators (I.-C.T. and K.-V.C.) was solved by the judgment of the third evaluator (P.-T.T.).

\subsection{Primary Outcomes (Changes in Cognitive Function)}

The primary outcomes were changes in cognitive function tests following at least 8-weeks of use of curcumin or placebo regimens. Cognitive function tests were categorized into nine domains, including overall performance, working memory, processing speed, language, episodic memory/visual learning, verbal memory, cognitive flexibility/problem solving, social cognition, and fluid cognition [90].

\subsection{Secondary Outcomes (Withdrawal Rates and Adverse Event Rates)}

The secondary outcomes were: (1) overall withdrawal rates; (2) specific withdrawal rates related to adverse effects; (3) overall adverse event rates; (4) gastrointestinal adverse event rates. For cells with zero-event, the zero was replaced by 0.5 to enable software calculation to properly include the study in to the analysis [91]. The aforementioned outcomes were quantified and synthesized using odds ratios (ORs).

\subsection{Data Extraction and Management}

Two independent authors (I.-C.T. and K.-V.C.) extracted data from the recruited studies, including demographic data, study design, details of curcumin supplement and placebo regimens, and the primary and secondary outcomes. In situations where the data were unavailable in the published articles and clinical trial registries, we contacted the corresponding authors to request the original data.

The combination of the results from the arms using different doses of curcumin was processed according to suggestions from the Cochrane Handbook for Systematic Reviews of Interventions [92]. For studies with multiple treatment arms, those without the use of curcumin or placebo regimens were not included in the quantitative analysis [93].

\subsection{Statistical Analysis}

Based on the heterogeneous target populations in the recruited studies, the metaanalysis was conducted using a random-effects model [94]. The meta-analysis was performed using the Comprehensive Meta-Analysis software, version 3 (Biostat, Englewood, NJ, USA). We chose Hedges' $g$ and $95 \%$ confidence intervals (95\% CI) as the main effect size (ES) of the primary outcomes (cognitive function changes in different domains). A Hedges' $g$ of $0.2,0.5$, and 0.8 , was considered a small, moderate, and large ES, respectively [95]. We chose ORs and their $95 \%$ CIs to investigate secondary outcomes (rates of withdrawal and adverse events). Subgroup analysis was performed based on the differences in the target populations, such as older adults, Alzheimer's disease, and schizophrenia. $I^{2}$ and Cochran's $Q$ statistics were used to evaluate the degree of heterogeneity among the studies. $I^{2}$ values of $25 \%, 50 \%$, and $75 \%$ were considered low, moderate, and high heterogeneity, respectively [96].

If there was more than one test in a specific domain, the test that best discriminated the outcome change was selected for meta-analysis inclusion by consensus of two authors (I.-C.T. and K.-V.C.). For example, serial 7 and serial 3 subtraction tests were used for the evaluation of working memory [36]. Sensitivity analysis was also performed by substituting the representative test with other similar assessments and re-analyzed to check whether 
the association between the intervention and outcomes changed significantly [91]. Potential publication bias was evaluated according to the Cochrane Handbook for Systematic Reviews of Interventions [97]. We visually inspected funnel plots when there were fewer than 10 datasets. Egger's regression tests were performed when there were 10 or more datasets. A two-tailed $p$-value less than 0.05 was considered statistically significant.

\section{Conclusions}

Following at least 8 weeks of nutritional supplementation, curcumin was found to improve working memory more than a placebo regimen. The results in the cognitive domain of processing speed were notable, with a borderline $p$-value, which may be significant if further trials are included. Moreover, curcumin was associated with higher odds of gastrointestinal AEs than the placebo regimen. Future RCTs should be designed and reported under the intention-to-treat principle to better reflect the true effectiveness of curcumin in the real world.

Supplementary Materials: The following are available online at https:/ / www.mdpi.com/article / 10.3390/ph14121235/s1, Figure S1: Subgroup analysis forest plot of the effect of curcumin on overall cognitive performance grouped by the participants' characteristics, Figure S2: Forest plot of the effect of curcumin on working memory using serial 3 as the index test in Cox et al.'s study, Figure S3: Forest plot of the effect of curcumin on working memory using virtual Morris water maze (vMWM) task as the index text in Cox et al.'s study, Figure S4: Forest plot of the effect of curcumin on language, Figure S5: Forest plot of the effect of curcumin on episodic memory/visual learning, Figure S6: Forest plot of the effect of curcumin on verbal memory, Figure S7: Forest plot of the effect of curcumin on cognitive flexibility/problem solving, Figure S8: Forest plot of the effect of curcumin on withdrawal rate compared with the placebo, Figure S9: Forest plot of the effect of curcumin on adverse event-related withdrawal rate compared with the placebo, Figure S10: Forest plot of the effect of curcumin on adverse event rate compared with the placebo, Figure S11: Funnel plot of the studies evaluating overall cognitive performance, Figure S12: Funnel plot of the studies evaluating working memory, Figure S13: Funnel plot of the studies evaluating processing speed, Figure S14: Funnel plot of the studies evaluating episodic memory/visual learning, Figure S15: Funnel plot of the studies evaluating verbal memory, Figure S16: Funnel plot of the studies evaluating cognitive flexibility/problem solving, Figure S17: Funnel plot of the studies evaluating withdrawal rate, Figure S18: Funnel plot of the studies evaluating the adverse event-related withdrawal rate, Figure S19: Funnel plot of studies the evaluating the adverse event rate, Figure S20: Funnel plot of the studies evaluating the gastrointestinal adverse event rate, Table S1: Excluded studies and reasons, Table S2: PRISMA Checklist, Table S3: Keywords and search results in different databases.

Author Contributions: Data curation, I.-C.T., P.-T.T. and K.-V.C.; formal analysis, I.-C.T. and K.-V.C.; investigation, C.-W.H., C.-H.C., P.-T.T. and K.-V.C.; methodology, C.-W.H., P.-T.T. and K.-V.C.; software, I.-C.T. and P.-T.T.; supervision, P.-T.T. and K.-V.C.; validation, C.-W.H., P.-T.T. and K.-V.C.; writing-original draft, I.-C.T.; writing-review and editing, C.-W.H., C.-H.C., P.-T.T. and K.-V.C. All authors have read and agreed to the published version of the manuscript.

Funding: This work was funded by National Taiwan University Hospital, Bei-Hu Branch; Ministry of Science and Technology (MOST 106-2314-B-002-180-MY3 and 109-2314-B-002-114-MY3); and the Taiwan Society of Ultrasound in Medicine. APC was funded by Ministry of Science and Technology and Taiwan Society of Ultrasound in Medicine.

Institutional Review Board Statement: This meta-analysis did not intervene or interact with humans nor collect identifiable private information, and thus does not require institutional review board approval.

Informed Consent Statement: Not applicable.

Data Availability Statement: Data is contained within the article and Supplementary Files.

Conflicts of Interest: The authors declare no conflict of interest. 


\section{References}

1. Shehzad, A.; Rehman, G.; Lee, Y.S. Curcumin in inflammatory diseases. Biofactors 2013, 39, 69-77. [CrossRef] [PubMed]

2. Parada, E.; Buendia, I.; Navarro, E.; Avendaño, C.; Egea, J.; López, M.G. Microglial HO-1 induction by curcumin provides antioxidant, antineuroinflammatory, and glioprotective effects. Mol. Nutr. Food Res. 2015, 59, 1690-1700. [CrossRef] [PubMed]

3. Sarker, M.R.; Franks, S.F. Efficacy of curcumin for age-associated cognitive decline: A narrative review of preclinical and clinical studies. Geroscience 2018, 40, 73-95. [CrossRef] [PubMed]

4. Kocaadam, B.; Şanlier, N. Curcumin, an active component of turmeric (Curcuma longa), and its effects on health. Crit. Rev. Food Sci. Nutr. 2017, 57, 2889-2895. [CrossRef]

5. Tayyem, R.F.; Heath, D.D.; Al-Delaimy, W.K.; Rock, C.L. Curcumin content of turmeric and curry powders. Nutr. Cancer 2006, 55, 126-131. [CrossRef]

6. Moore, T.L.; Bowley, B.; Shultz, P.; Calderazzo, S.; Shobin, E.; Killiany, R.J.; Rosene, D.L.; Moss, M.B. Chronic curcumin treatment improves spatial working memory but not recognition memory in middle-aged rhesus monkeys. Geroscience 2017, 39, 571-584. [CrossRef]

7. Bassani, T.B.; Turnes, J.M.; Moura, E.L.R.; Bonato, J.M.; Cóppola-Segovia, V.; Zanata, S.M.; Oliveira, R.; Vital, M. Effects of curcumin on short-term spatial and recognition memory, adult neurogenesis and neuroinflammation in a streptozotocin-induced rat model of dementia of Alzheimer's type. Behav. Brain Res. 2017, 335, 41-54. [CrossRef]

8. Noorafshan, A.; Karimi, F.; Karbalay-Doust, S.; Kamali, A.M. Using curcumin to prevent structural and behavioral changes of medial prefrontal cortex induced by sleep deprivation in rats. Excli J. 2017, 16, 510-520. [CrossRef]

9. Ng, T.P.; Chiam, P.C.; Lee, T.; Chua, H.C.; Lim, L.; Kua, E.H. Curry consumption and cognitive function in the elderly. Am. J. Epidemiol. 2006, 164, 898-906. [CrossRef]

10. Ringman, J.M.; Frautschy, S.A.; Teng, E.; Begum, A.N.; Bardens, J.; Beigi, M.; Gylys, K.H.; Badmaev, V.; Heath, D.D.; Apostolova, L.G.; et al. Oral curcumin for Alzheimer's disease: Tolerability and efficacy in a 24-week randomized, double blind, placebo-controlled study. Alzheimers Res. Ther. 2012, 4, 43. [CrossRef]

11. Rainey-Smith, S.R.; Brown, B.M.; Sohrabi, H.R.; Shah, T.; Goozee, K.G.; Gupta, V.B.; Martins, R.N. Curcumin and cognition: A randomised, placebo-controlled, double-blind study of community-dwelling older adults. Br. J. Nutr. 2016, 115, $2106-2113$. [CrossRef]

12. Zhu, L.N.; Mei, X.; Zhang, Z.G.; Xie, Y.P.; Lang, F. Curcumin intervention for cognitive function in different types of people: A systematic review and meta-analysis. Phytother. Res. 2019, 33, 524-533. [CrossRef]

13. Baum, L.; Lam, C.W.; Cheung, S.K.; Kwok, T.; Lui, V.; Tsoh, J.; Lam, L.; Leung, V.; Hui, E.; Ng, C.; et al. Six-month randomized, placebo-controlled, double-blind, pilot clinical trial of curcumin in patients with Alzheimer disease. J. Clin. Psychopharmacol. 2008, 28, 110-113. [CrossRef]

14. Cox, K.H.; Pipingas, A.; Scholey, A.B. Investigation of the effects of solid lipid curcumin on cognition and mood in a healthy older population. J. Psychopharmacol. 2015, 29, 642-651. [CrossRef]

15. Small, G.W.; Siddarth, P.; Li, Z.; Miller, K.J.; Ercoli, L.; Emerson, N.D.; Martinez, J.; Wong, K.P.; Liu, J.; Merrill, D.A.; et al. Memory and Brain Amyloid and Tau Effects of a Bioavailable Form of Curcumin in Non-Demented Adults: A Double-Blind, Placebo-Controlled 18-Month Trial. Am. J. Geriatr. Psychiatry 2018, 26, 266-277. [CrossRef]

16. Wynn, J.K.; Green, M.F.; Hellemann, G.; Karunaratne, K.; Davis, M.C.; Marder, S.R. The effects of curcumin on brain-derived neurotrophic factor and cognition in schizophrenia: A randomized controlled study. Schizophr. Res. 2018, 195, 572-573. [CrossRef]

17. Funahashi, S. Working Memory in the Prefrontal Cortex. Brain Sci. 2017, 7, 49. [CrossRef]

18. Murman, D.L. The Impact of Age on Cognition. Semin. Hear. 2015, 36, 111-121. [CrossRef]

19. Kirova, A.M.; Bays, R.B.; Lagalwar, S. Working memory and executive function decline across normal aging, mild cognitive impairment, and Alzheimer's disease. Biomed. Res. Int. 2015, 2015, 748212. [CrossRef]

20. Bowie, C.R.; Harvey, P.D. Cognitive deficits and functional outcome in schizophrenia. Neuropsychiatr. Dis. Treat. 2006, 2, 531-536. [CrossRef]

21. Soleimani, V.; Sahebkar, A.; Hosseinzadeh, H. Turmeric (Curcuma longa) and its major constituent (curcumin) as nontoxic and safe substances: Review. Phytother. Res. 2018, 32, 985-995. [CrossRef]

22. Turmeric. In Drugs and Lactation Database (LactMed); National Library of Medicine (US): Bethesda, MD, USA, 2006.

23. Sharma, R.A.; Euden, S.A.; Platton, S.L.; Cooke, D.N.; Shafayat, A.; Hewitt, H.R.; Marczylo, T.H.; Morgan, B.; Hemingway, D.; Plummer, S.M.; et al. Phase I clinical trial of oral curcumin: Biomarkers of systemic activity and compliance. Clin. Cancer Res. 2004, 10, 6847-6854. [CrossRef]

24. Lee, M.S.; Wahlqvist, M.L.; Chou, Y.C.; Fang, W.H.; Lee, J.T.; Kuan, J.C.; Liu, H.Y.; Lu, T.M.; Xiu, L.; Hsu, C.C.; et al. Turmeric improves post-prandial working memory in pre-diabetes independent of insulin. Asia Pac. J. Clin. Nutr. 2014, $23,581-591$. [CrossRef]

25. Ross, S.M. Curcuma longa (Theracumin $\left.{ }^{\circledR}\right)$ : A Bioavailable Form of Curcumin and Its Cognitive Benefits. Holist. Nurs. Pract 2018, 32, 217-220. [CrossRef]

26. Kucukgoncu, S.; Guloksuz, S.; Tek, C. Effects of Curcumin on Cognitive Functioning and Inflammatory State in Schizophrenia: A Double-Blind, Placebo-Controlled Pilot Trial. J. Clin. Psychopharmacol. 2019, 39, 182-184. [CrossRef] 
27. Cox, K.H.M.; White, D.J.; Pipingas, A.; Poorun, K.; Scholey, A. Further Evidence of Benefits to Mood and Working Memory from Lipidated Curcumin in Healthy Older People: A 12-Week, Double-Blind, Placebo-Controlled, Partial Replication Study. Nutrients 2020, 12, 1678. [CrossRef]

28. Kuszewski, J.C.; Howe, P.R.C.; Wong, R.H.X. Evaluation of Cognitive Performance following Fish-Oil and Curcumin Supplementation in Middle-Aged and Older Adults with Overweight or Obesity. J. Nutr. 2020, 150, 3190-3199. [CrossRef]

29. Curcumin in Patients With Mild to Moderate Alzheimer's Disease. ClinicalTrials.Gov. Available online: https://clinicaltrials. gov/ct2/show/nct00099710 (accessed on 13 August 2021).

30. Australian New Zealand Clinical Trials Registry. Biocurcumax from Curry Spice Turmeric in Retaining Cognitive Function. Available online: https:/ / www.anzctr.org.au/Trial/Registration/TrialReview.aspx?ACTRN=12611000437965 (accessed on 13 August 2021).

31. 18-Month Study of Memory Effects of Curcumin. Study Results. ClinicalTrials.Gov. Available online: https:/ clinicaltrials.gov / ct2/show/results/NCT01383161 (accessed on 13 August 2021).

32. Curcumin as a Novel Treatment to Improve Cognitive Dysfunction in Schizophrenia. ClinicalTrials.Gov. Available online: https: / / ClinicalTrials.gov/show / NCT02104752 (accessed on 13 August 2021).

33. A Pilot Trial of Curcumin Effects on Cognition in Schizophrenia. ClinicalTrials.Gov. Available online: https://clinicaltrials.gov / ct2/show / NCT02476708 (accessed on 13 August 2021).

34. Australian New Zealand Clinical Trials Registry. Investigation of the Effects of Longvida Curcumin on Cognitive Function, Mood and Biomarkers of Health. Available online: https:/ / www.anzctr.org.au/Trial/Registration/TrialReview.aspx?id=370499 (accessed on 13 August 2021).

35. Australian New Zealand Clinical Trials Registry. Cardiometabolic and cognitive benefits of omega-3 polyunsaturated fatty acids and curcumin supplementation in older, sedentary and overweight/obese adults. Available online: https://www.anzctr.org.au/ Trial/Registration/TrialReview.aspx?id=370788 (accessed on 13 August 2021).

36. Bristow, T.; Jih, C.S.; Slabich, A.; Gunn, J. Standardization and adult norms for the sequential subtracting tasks of serial 3's and 7's. Appl. Neuropsychol. Adult 2016, 23, 372-378. [CrossRef]

37. Kaufman, D.; Geyer, H.; Milstein, M. Kaufman's Clinical Neurology for Psychiatrists. In Dementia; Elsevier: Amsterdam, The Netherlands, 2017; pp. 105-149.

38. Kuszewski, J.C.; Wong, R.H.X.; Howe, P.R.C. Can Curcumin Counteract Cognitive Decline? Clinical Trial Evidence and Rationale for Combining w-3 Fatty Acids with Curcumin. Adv. Nutr. 2018, 9, 105-113. [CrossRef]

39. Higgins, J.P.T.; Green, S.E. Cochrane Handbook for Systematic Reviews of Interventions. Version 5.1.0. Available online: https://training.cochrane.org/handbook/archive/v5.1/ (accessed on 13 August 2021).

40. De Berardis, D.; Campanella, D.; Gambi, F.; La Rovere, R.; Carano, A.; Conti, C.M.; Sivestrini, C.; Serroni, N.; Piersanti, D.; Di Giuseppe, B.; et al. The role of C-reactive protein in mood disorders. Int. J. Immunopathol. Pharmacol. 2006, 19, 721-725. [CrossRef]

41. Orsolini, L.; Sarchione, F.; Vellante, F.; Fornaro, M.; Matarazzo, I.; Martinotti, G.; Valchera, A.; Di Nicola, M.; Carano, A.; Di Giannantonio, M.; et al. Protein-C Reactive as Biomarker Predictor of Schizophrenia Phases of Illness? A Systematic Review. Curr. Neuropharmacol. 2018, 16, 583-606. [CrossRef] [PubMed]

42. Gagliardi, S.; Morasso, C.; Stivaktakis, P.; Pandini, C.; Tinelli, V.; Tsatsakis, A.; Prosperi, D.; Hickey, M.; Corsi, F.; Cereda, C. Curcumin Formulations and Trials: What's New in Neurological Diseases. Molecules 2020, 25, 5389. [CrossRef] [PubMed]

43. Kandezi, N.; Mohammadi, M.; Ghaffari, M.; Gholami, M.; Motaghinejad, M.; Safari, S. Novel Insight to Neuroprotective Potential of Curcumin: A Mechanistic Review of Possible Involvement of Mitochondrial Biogenesis and PI3/Akt/ GSK3 or PI3/Akt/CREB/BDNF Signaling Pathways. Int. J. Mol. Cell Med. 2020, 9, 1-32. [CrossRef] [PubMed]

44. Ashtary-Larky, D.; Rezaei Kelishadi, M.; Bagheri, R.; Moosavian, S.P.; Wong, A.; Davoodi, S.H.; Khalili, P.; Dutheil, F.; Suzuki, K.; Asbaghi, O. The Effects of Nano-Curcumin Supplementation on Risk Factors for Cardiovascular Disease: A GRADE-Assessed Systematic Review and Meta-Analysis of Clinical Trials. Antioxidants 2021, 10, 1015. [CrossRef]

45. Chandan, S.; Mohan, B.P.; Chandan, O.C.; Ahmad, R.; Challa, A.; Tummala, H.; Singh, S.; Dhawan, P.; Ponnada, S.; Singh, A.B.; et al. Curcumin use in ulcerative colitis: Is it ready for prime time? A systematic review and meta-analysis of clinical trials. Ann. Gastroenterol. 2020, 33, 53-58. [CrossRef]

46. Suhett, L.G.; de Miranda Monteiro Santos, R.; Silveira, B.K.S.; Leal, A.C.G.; de Brito, A.D.M.; de Novaes, J.F.; Lucia, C.M.D. Effects of curcumin supplementation on sport and physical exercise: A systematic review. Crit. Rev. Food Sci. Nutr. 2021, 61, 946-958. [CrossRef]

47. Fernández-Lázaro, D.; Mielgo-Ayuso, J.; Seco Calvo, J.; Córdova Martínez, A.; Caballero García, A.; Fernandez-Lazaro, C.I. Modulation of Exercise-Induced Muscle Damage, Inflammation, and Oxidative Markers by Curcumin Supplementation in a Physically Active Population: A Systematic Review. Nutrients 2020, 12, 501. [CrossRef]

48. Mansouri, K.; Rasoulpoor, S.; Daneshkhah, A.; Abolfathi, S.; Salari, N.; Mohammadi, M.; Rasoulpoor, S.; Shabani, S. Clinical effects of curcumin in enhancing cancer therapy: A systematic review. BMC Cancer 2020, 20, 791. [CrossRef]

49. Howe, P.R.C.; Kuszewski, J.C.; Wong, R.H.X. Curcumin for Cognition-Does the Path Lie in the Cerebral Circulation? Adv. Nutr. 2019, 10, 182. [CrossRef] 
50. Naeimi, R.; Safarpour, F.; Hashemian, M.; Tashakorian, H.; Ahmadian, S.R.; Ashrafpour, M.; Ghasemi-Kasman, M. Curcuminloaded nanoparticles ameliorate glial activation and improve myelin repair in lyolecithin-induced focal demyelination model of rat corpus callosum. Neurosci. Lett. 2018, 674, 1-10. [CrossRef]

51. Wang, Y.F.; Gu, Y.T.; Qin, G.H.; Zhong, L.; Meng, Y.N. Curcumin ameliorates the permeability of the blood-brain barrier during hypoxia by upregulating heme oxygenase-1 expression in brain microvascular endothelial cells. J. Mol. Neurosci. 2013, 51, 344-351. [CrossRef]

52. Wang, Y.; Luo, J.; Li, S.Y. Nano-Curcumin Simultaneously Protects the Blood-Brain Barrier and Reduces M1 Microglial Activation During Cerebral Ischemia-Reperfusion Injury. ACS Appl. Mater Interfaces 2019, 11, 3763-3770. [CrossRef]

53. Gorelick, P.B.; Scuteri, A.; Black, S.E.; Decarli, C.; Greenberg, S.M.; Iadecola, C.; Launer, L.J.; Laurent, S.; Lopez, O.L.; Nyenhuis, D.; et al. Vascular contributions to cognitive impairment and dementia: A statement for healthcare professionals from the american heart association/american stroke association. Stroke 2011, 42, 2672-2713. [CrossRef]

54. Watanabe, K.; Funahashi, S. A dual-task paradigm for behavioral and neurobiological studies in nonhuman primates. J. Neurosci. Methods 2015, 246, 1-12. [CrossRef]

55. Watanabe, K.; Funahashi, S. Neural mechanisms of dual-task interference and cognitive capacity limitation in the prefrontal cortex. Nat. Neurosci. 2014, 17, 601-611. [CrossRef]

56. Noorafshan, A.; Abdollahifar, M.A.; Asadi-Golshan, R.; Rashidian-Rashidabadi, A.; Karbalay-Doust, S. Curcumin and sertraline prevent the reduction of the number of neurons and glial cells and the volume of rats' medial prefrontal cortex induced by stress. Acta Neurobiol. Exp. (Wars) 2014, 74, 44-53.

57. Noorafshan, A.; Asadi-Golshan, R.; Abdollahifar, M.A.; Karbalay-Doust, S. Protective role of curcumin against sulfite-induced structural changes in rats' medial prefrontal cortex. Nutr. Neurosci. 2015, 18, 248-255. [CrossRef]

58. Magistro, D.; Takeuchi, H.; Nejad, K.K.; Taki, Y.; Sekiguchi, A.; Nouchi, R.; Kotozaki, Y.; Nakagawa, S.; Miyauchi, C.M.; Iizuka, K.; et al. The Relationship between Processing Speed and Regional White Matter Volume in Healthy Young People. PLoS ONE 2015, 10, e0136386. [CrossRef]

59. Nilsson, J.; Thomas, A.J.; O’Brien, J.T.; Gallagher, P. White matter and cognitive decline in aging: A focus on processing speed and variability. J. Int. Neuropsychol. Soc. 2014, 20, 262-267. [CrossRef]

60. Abel, S.; Vavasour, I.; Lee, L.E.; Johnson, P.; Ackermans, N.; Chan, J.; Dvorak, A.; Schabas, A.; Wiggermann, V.; Tam, R.; et al. Myelin Damage in Normal Appearing White Matter Contributes to Impaired Cognitive Processing Speed in Multiple Sclerosis. J. Neuroimaging 2020, 30, 205-211. [CrossRef]

61. Kerchner, G.A.; Racine, C.A.; Hale, S.; Wilheim, R.; Laluz, V.; Miller, B.L.; Kramer, J.H. Cognitive processing speed in older adults: Relationship with white matter integrity. PLOS ONE 2012, 7, e50425. [CrossRef]

62. Bartzokis, G. Age-related myelin breakdown: A developmental model of cognitive decline and Alzheimer's disease. Neurobiol. Aging 2004, 25, 5-18. [CrossRef]

63. O'Sullivan, M.; Jones, D.K.; Summers, P.E.; Morris, R.G.; Williams, S.C.; Markus, H.S. Evidence for cortical "disconnection" as a mechanism of age-related cognitive decline. Neurology 2001, 57, 632-638. [CrossRef]

64. Daverey, A.; Agrawal, S.K. Curcumin Protects against White Matter Injury through NF-kB and Nrf2 Cross Talk. J. Neurotrauma 2020, 37, 1255-1265. [CrossRef]

65. GRAS Notice (GRN) No. 822. U.S. Food \& Drug Administration. GRAS Notice Inventory. Available online: https://www.fda. gov/media/132575/download (accessed on 13 August 2021).

66. NTP Toxicology and Carcinogenesis Studies of Turmeric Oleoresin (CAS No. 8024-37-1) (Major Component 79\%-85\% Curcumin, CAS No. 458-37-7) in F344/N Rats and B6C3F1 Mice (Feed Studies). Natl. Toxicol. Program Tech. Rep. Ser. 1993, 427, 1-275.

67. Atsumi, T.; Fujisawa, S.; Tonosaki, K. Relationship between intracellular ROS production and membrane mobility in curcuminand tetrahydrocurcumin-treated human gingival fibroblasts and human submandibular gland carcinoma cells. Oral Dis. 2005, 11, 236-242. [CrossRef]

68. Sandur, S.K.; Ichikawa, H.; Pandey, M.K.; Kunnumakkara, A.B.; Sung, B.; Sethi, G.; Aggarwal, B.B. Role of pro-oxidants and antioxidants in the anti-inflammatory and apoptotic effects of curcumin (diferuloylmethane). Free Radic. Biol. Med. 2007, 43, 568-580. [CrossRef] [PubMed]

69. McNally, S.J.; Harrison, E.M.; Ross, J.A.; Garden, O.J.; Wigmore, S.J. Curcumin induces heme oxygenase 1 through generation of reactive oxygen species, p38 activation and phosphatase inhibition. Int. J. Mol. Med. 2007, 19, 165-172. [CrossRef] [PubMed]

70. Gupta, S.K. Intention-to-treat concept: A review. Perspect. Clin. Res. 2011, 2, 109-112. [CrossRef] [PubMed]

71. AustralianVitamins.com. Blackmores Brain Active. Available online: https://www.australianvitamins.com/product/blackmoresvitamins-brain-active (accessed on 24 November 2021).

72. Mane Kancor®. Curcumin. Available online: https://manekancor.com/natural-colors-c-capture-pigments/curcumin (accessed on 24 November 2021).

73. Arjuna Natural®. Biocurcumax ${ }^{\circledR}\left(\right.$ aka BCM-95®or Curcugreen $\left.{ }^{\circledR}\right)$. Available online: https://arjunanatural.com/bcm-95 -bioavailable-curcumin/ (accessed on 24 November 2021).

74. Sabinsa®. Curcumin C3 Complex®. Available online: https://curcuminoids.com/ (accessed on 24 November 2021).

75. Verdure Sciences ${ }^{\circledR}$. Longvida ${ }^{\circledR S L C P}{ }^{\mathrm{TM}}$ (solid lipid curcumin particles). Available online: https://vs-corp.com/longvida/ (accessed on 24 November 2021).

76. Theravalues ${ }^{\circledR}$. Theracurmin ${ }^{\circledR}$. Available online: https://theravalues.com/english/products/ (accessed on 24 November 2021). 
77. Katsidoni, V.; Alexiou, P.; Fotiadou, M.; Pelecanou, M.; Sagnou, M.; Panagis, G. Curcumin, demethoxycurcumin and bisdemethoxycurcumin differentially inhibit morphine's rewarding effect in rats. Psychopharmacology 2014, 231, 4467-4478. [CrossRef]

78. Anand, P.; Thomas, S.G.; Kunnumakkara, A.B.; Sundaram, C.; Harikumar, K.B.; Sung, B.; Tharakan, S.T.; Misra, K.; Priyadarsini, I.K.; Rajasekharan, K.N.; et al. Biological activities of curcumin and its analogues (Congeners) made by man and Mother Nature. Biochem. Pharmacol. 2008, 76, 1590-1611. [CrossRef]

79. Agrawal, S.S.; Gullaiya, S.; Dubey, V.; Singh, V.; Kumar, A.; Nagar, A.; Tiwari, P. Neurodegenerative Shielding by Curcumin and Its Derivatives on Brain Lesions Induced by 6-OHDA Model of Parkinson's Disease in Albino Wistar Rats. Cardiovasc. Psychiatry Neurol. 2012, 2012, 942981. [CrossRef]

80. Yin, F.; Sancheti, H.; Patil, I.; Cadenas, E. Energy metabolism and inflammation in brain aging and Alzheimer's disease. Free Radic. Biol. Med. 2016, 100, 108-122. [CrossRef]

81. Ozben, T.; Ozben, S. Neuro-inflammation and anti-inflammatory treatment options for Alzheimer's disease. Clin. Biochem. 2019, 72, 87-89. [CrossRef]

82. Dauwan, M.; Begemann, M.J.H.; Slot, M.I.E.; Lee, E.H.M.; Scheltens, P.; Sommer, I.E.C. Physical exercise improves quality of life, depressive symptoms, and cognition across chronic brain disorders: A transdiagnostic systematic review and meta-analysis of randomized controlled trials. J. Neurol. 2021, 268, 1222-1246. [CrossRef]

83. Sterne, J.A.C.; Savovic, J.; Page, M.J.; Elbers, R.G.; Blencowe, N.S.; Boutron, I.; Cates, C.J.; Cheng, H.Y.; Corbett, M.S.; Eldridge, S.M.; et al. RoB 2: A revised tool for assessing risk of bias in randomised trials. BMJ 2019, 366, 14898. [CrossRef]

84. Page, M.J.; McKenzie, J.E.; Bossuyt, P.M.; Boutron, I.; Hoffmann, T.C.; Mulrow, C.D.; Shamseer, L.; Tetzlaff, J.M.; Akl, E.A.; Brennan, S.E.; et al. The PRISMA 2020 statement: An updated guideline for reporting systematic reviews. BMJ 2021, $372, \mathrm{n} 71$. [CrossRef]

85. Shea, B.J.; Reeves, B.C.; Wells, G.; Thuku, M.; Hamel, C.; Moran, J.; Moher, D.; Tugwell, P.; Welch, V.; Kristjansson, E.; et al. AMSTAR 2: A critical appraisal tool for systematic reviews that include randomised or non-randomised studies of healthcare interventions, or both. BMJ 2017, 358, j4008. [CrossRef]

86. Tsai, I.-C.; Chang, K.-V. The Effect of Curcumin Differs on Individual Cognitive Domains across Different Patient Populations: A Systematic Review and Meta-Analysis. Available online: https://inplasy.com/inplasy-2021-9-0085/ (accessed on 24 September 2021).

87. Voulgaropoulou, S.D.; van Amelsvoort, T.; Prickaerts, J.; Vingerhoets, C. The effect of curcumin on cognition in Alzheimer's disease and healthy aging: A systematic review of pre-clinical and clinical studies. Brain Res. 2019, 1725, 146476. [CrossRef]

88. How Long Does It Take for Turmeric to Work? The Tumeric. Available online: https://theturmeric.co/blogs/the-root/how-longdoes-it-take-for-turmeric-to-work (accessed on 13 August 2021).

89. Meixner, M. Turmeric Dosage: How Much Should You Take Per Day? Healthline. Available online: https://www.healthline. com/nutrition/turmeric-dosage (accessed on 13 August 2021).

90. Harvey, P.D. Domains of cognition and their assessment. Dialogues Clin. Neurosci. 2019, 21, 227-237. [CrossRef]

91. Deeks, J.J.; Higgins, J.P.T.; Altman, D.G. Chapter 10: Analysing Data and Undertaking Meta-Analyses. Cochrane Handbook for Systematic Reviews of Interventions. Version 6.2. Available online: https://training.cochrane.org/handbook/current/chapter-10 (accessed on 13 August 2021).

92. Higgins, J.P.T.; Li, T.; Deeks, J.J. Chapter 6: Choosing Effect Measures and Computing Estimates of Effect. Cochrane Handbook for Systematic Reviews of Interventions. Version 6.2. Available online: https://training.cochrane.org/handbook/current/chapter-06 (accessed on 13 August 2021).

93. Higgins, J.P.T.; Eldridge, S.; Li, T. Chapter 23: Including Variants on Randomized Trials. Cochrane Handbook for Systematic Reviews of Interventions. Version 6.2. Available online: https://training.cochrane.org/handbook/current/chapter-23 (accessed on 13 August 2021).

94. Borenstein, M.; Hedges, L.V.; Higgins, J.P.T.; Rothstein, H.R. Fixed-Effect versus Random-Effects Models. In Introduction to Meta-Analysis; Borenstein, M., Ed.; Wiley: Hoboken, NJ, USA, 2009; pp. 77-86.

95. Hedges, L.V. Distribution theory for Glass's estimator of effect size and related estimators. J. Educ. Stat. 1981, 6, 107-128. [CrossRef]

96. Higgins, J.P.T.; Thompson, S.G.; Deeks, J.J.; Altman, D.G. Measuring inconsistency in meta-analyses. BMJ 2003, 327, 557-560. [CrossRef]

97. Page, M.J.; Higgins, J.P.T.; Sterne, J.A.C. Chapter 13: Assessing Risk of Bias due to Missing Results in a Synthesis. Cochrane Handbook for Systematic Reviews of Interventions. Version 6.2. Available online: https://training.cochrane.org/handbook/ current/chapter-13 (accessed on 13 August 2021). 